LETTER TO JMG

\title{
Association of PLUNC gene polymorphisms with susceptibility to nasopharyngeal carcinoma in a Chinese population
}

\author{
Y He, G Zhou, Y Zhai, X Dong, L Lv, F He, K Yao
}

J Med Genet 2005;42:172-176. doi: 10.1136/jimg.2004.022616

$\mathrm{N}$ asopharyngeal carcinoma (NPC) is a serious health problems in the southern Chinese population, with an incidence rate ranging from 15 to 50 per 100000 . NPC is an epithelial malignancy with a striking racial and geographic distribution differences. ${ }^{2}$ High incidence rates are observed in the southeast Chinese population, and similar rates have been reported in these people wherever they have migrated, including Singapore, ${ }^{3}$ Taiwan, ${ }^{4}$ and Hong Kong. ${ }^{5}$ These incidence rates are almost 100 fold higher than in white populations. ${ }^{2}$ The marked racial and geographic differences in NPC susceptibility are considered a multifactorial and polygenic event with environmental and genetic components and correlation with Epstein-Barr virus infection. ${ }^{2}{ }^{6-10}$

Genetic mapping of variants conferring a small disease risk can identify pathways in complex disorders. Thus, the hope of resolving the genetic aetiology of NPC and the mechanisms of racial and geographic differences in NPC susceptibility has prompted a search for genetic variants in gene candidates thought to play a role in the pathogenesis of the NPC. A genetic linkage study based on affected sibling pairs collected from different Chinese populations in southeast Asia, which located the susceptibility locus to within the $6 \mathrm{p} 22$ region, supported the involvement of the human leukocyte antigens (HLA) in the pathogenesis of NPC. ${ }^{11}$ Recently, two genomewide searches, carried out in 20 Cantonese speaking families from Guangdong province and 18 families from Hunan province in southern China, provided evidences of susceptibility loci for NPC on chromosome 4p15.1-q12 and 3p21.3121.2, respectively. ${ }^{12}{ }^{13}$ Case-control studies have established associations between specific HLA molecules and NPC in several populations including Asians, whites, and North Africans. ${ }^{14-16}$ In addition to the HLA, some non-HLA loci, including the heat shock protein 70-2 (HSP70-2) ${ }^{17}$ cyclin D1 (CCNDI), ${ }^{18}$ glutathione S-transferase Ml (GSTMl), ${ }^{19}$ and CYP2E1 genes ${ }^{4}$ have also shown associations with susceptibility to NPC. Based on the fact that the disease susceptibility to NPC is determined at different functional levels, such as metabolism of carcinogenic constituents, tumour antigen presentation, cell cycle regulation, and antigenic peptide chaperones, we hypothesised that an unknown number of other unidentified genes are likely to modify the susceptibility to NPC.

PLUNC (palate, lung, and nasal epithelial clone, also designated YHI, LUNX, NASG, SPURT, and SPLUNCl) is a newly identified human homologue of the murine plunc gene, and, like the mouse gene, is specifically expressed in the upper airways and nasopharyngeal regions..$^{20-25}$ The abnormal expression of PLUNC may be an important molecular event in NPC development; it was found to be downregulated in 34/48 NPC biopsies. ${ }^{24}$ It has been reported that CNE-2Z cells transfected with PLUNC had a significant decrease in cell

\section{Key points}

- Nasopharyngeal carcinoma (NPC) is a serious health problems in people from southern China, with an incidence rate ranging from 15 to 50 per 100000 . The mechanisms underlying susceptibility to NPC remain undetermined. The abnormal expression of the PLUNC (palate, lung, and nasal epithelial clone) gene may be an important molecular event in NPC.

- The aim of this study was to screen single nucleotide polymorphisms (SNPs) in the PLUNC gene and determine whether they are associated with susceptibility to NPC in the Chinese population.

- A total of eight SNPs were identified in all exons, relevant exon-intron boundaries, and the $\sim 2 \mathrm{~kb}$ promoter region of PLUNC gene. Three haplotype tagged SNPs (htSNPs) were genotyped in a casecontrol Chinese population including 239 unrelated patients with NPC and 286 healthy controls. Two promoter SNPs, C-2128T and C-1888T, showed significant associations with susceptibility to NPC $(O R=2.8-3.3, p<0.001)$. Furthermore, the distribution of haplotypes, which were constructed based on the polymorphisms C-2128T and C-1888T, was significantly different between NPC patients and controls, indicating that the individuals with haplotype C-C had significantly increased susceptibility to NPC $(\mathrm{OR}=1.86,95 \% \mathrm{Cl}=1.34-2.56, \mathrm{p}=0.00016)$.

- We conclude that the genetic variation in PLUNC may influence susceptibility to NPC in the Chinese population, and may help future treatment and prevention of this disorder.

proliferation. $^{21}$ More interestingly, this gene is located on chromosome segment 20q11.2, ${ }^{26}$ and the $\operatorname{loss}^{27}{ }^{28}$ or gain $^{29}$ of chromosome arm 20q has been previously described in NPC.

On the basis of the potential functional relevance of PLUNC in the pathogenesis of NPC in vivo and in vitro, we hypothesised that PLUNC might be an excellent biological candidate susceptibility gene for NPC. It is expected that genetic polymorphisms within PLUNC could result in genotype dependent differences in susceptibility to NPC. In the present study, we therefore systematically screened single nucleotide polymorphisms (SNPS) in PLUNC, and investigated association of the polymorphisms in PLUNC with susceptibility to NPC in the Chinese population. 


\section{MATERIALS AND METHODS \\ Patients and controls}

The case-control population contained 525 adult unrelated Chinese who were selected from the same population living in southeastern China between February 2000 and May 2003 (table 1). A total of 239 NPC patients were recruited from Nanfang Hospital and Jianmen Center Hospital in Guangzhou City. The only selection criterion for patients was that their NPC diagnosis had been pathologically confirmed. In $90.4 \%$ patients, the diagnosis was poorly differentiated squamous cell carcinoma. The patients (163 men; 76 women) had a mean (SD) age of 46.9 (11.2) years. The control group consisted of 286 unrelated blood donors, and laboratory and medical staff. Selection criteria for controls were no evidence of any personal or family history of cancer or other serious illness. The mean age of the control group (151 males and 135 females) was 47.2 (12.8) years. There was no significant difference between patients and control subjects in terms of mean age distribution. However, although an effort was made to obtain a frequency match on gender distribution between cases and controls, there were more men in the case group than in the control group $(68.2 \%$ $\left.v 52.8 \%, \chi^{2}=12.2, \mathrm{p}<0.01\right)$. Written informed consent was obtained from all the subjects, and the study was performed with the approval of the ethics committee of Chinese Human Genome.

\section{SNP discovery}

SNP screening of all exons, relevant intron-exon boundaries and the approximately $2 \mathrm{~kb}$ promoter region of PLUNC (GenBank accession no. GI:17458490) was performed by PCR direct sequencing as described previously. ${ }^{30}{ }^{31}$ The exact sequence regions investigated are indicated in fig lA by first and last nucleotide position. The screening panel included 27 unrelated individuals randomly selected from the 525 individuals, regardless of disease status. The sample size gave us $95 \%$ probability of detecting alleles with a minimal frequency of $5.4 \%{ }^{32}$ Briefly, the primers for the target regions were designed using the web based software Primer 3.0 (http://www-genome.wi.mit.edu/). DNA samples from 27 Chinese individuals were amplified and purified, then the PCR products were sequenced using an ABI Prism Dye Terminator Sequencing kit with AmpliTaq DNA polymerase (ABI, Foster City, CA, USA) and loaded onto an ABI 3700 sequencer. SNP candidates were identified by the PolyPhred program (http://droog.mbt.washington.edu/PolyPhred.html) and inspected by two observers. SNP positions and individual genotypes were confirmed by reamplifying and resequencing the SNP sites from the opposite strand. Primers are available on request.

\begin{tabular}{|c|c|c|}
\hline Variable & $\begin{array}{l}\text { NPC patients } \\
(n=239)\end{array}$ & $\begin{array}{l}\text { Controls } \\
(n=286)\end{array}$ \\
\hline \multicolumn{3}{|l|}{ Sex (\%) } \\
\hline Male & $163(68.2)^{*}$ & $151(52.8)$ \\
\hline Female & $76(31.8)^{*}$ & $135(47.2)$ \\
\hline Mean (SD) age (years) & $46.9(11.2)$ & $47.2(12.8)$ \\
\hline \multirow{2}{*}{\multicolumn{3}{|c|}{$\begin{array}{l}\text { Histological type (\%) } \\
\text { Poorly differentiated }\end{array}$}} \\
\hline & & \\
\hline squamous cell carcinoma & $216(90.4)$ & \\
\hline Others $†$ & $23(9.6)$ & \\
\hline
\end{tabular}

${ }^{*} p<0.01$, compared with controls; tohers include poorly differentiated adenocarcinoma $(n=8)$, higher differentiated squamous cell carcinoma $(n=6)$, and undifferentiated cancer $(n=9)$.
Haplotype construction and htSNP determination

PLUNC haplotypes from the unrelated Chinese samples were assigned by the PHASE program, ${ }^{33}$ an implementation of the Stephens-Donnelly method of haplotype reconstruction, which uses a Bayesian approach incorporating a priori expectations of haplotypic structure from population genetic and coalescent theory. The program htSNP2 (http://wwwgene.cimr.cam.ac.uk/clayton/software/) was used to determine the htSNPs as described previously. ${ }^{34}$

\section{SNP genotyping}

We extracted genomic DNA from peripheral blood leukocytes of $5 \mathrm{ml}$ whole blood using standard phenol/chloroform protocols. DNA samples were diluted to $8 \mathrm{ng} / \mu \mathrm{l}$ and placed in 96 well plates; each 96 well plate contained 94 samples and two controls containing water with no DNA. Three htSNPs (A-3348C, C-2128T, and C-1888T) were then selected for genotyping in the case-control population using PCR direct sequencing or PCR-RFLP analysis.

The polymorphism A-3348C was genotyped by PCR direct sequencing. The primers 5'-TGCCAGGTGCTCTCCATATTT-3' and 5'-TTTCATTAACTGGCTGCACAAA-3' were used for amplifying and sequencing the target region. PCR conditions were identical to those for SNP discovery, ${ }^{30}{ }^{31}$ except for an annealing temperature of $56.5^{\circ} \mathrm{C}$.

For the C-1888T polymorphism, an amplification using forward primer 5'-AGGTGAGACAGTTAAGCTATTTGAT-3' and reverse primer $5^{\prime}$-AGGGGCCAAGAGATGAGACT-3' ${ }^{\top}$ was performed. An FbaI recognition site was introduced by a one base mismatch (underlined) in the forward primer. PCR conditions were identical to those for SNPs discovery ${ }^{30} 31$ except for an annealing temperature of $54.8^{\circ} \mathrm{C}$ and a total reaction volume of $25 \mu \mathrm{l}$. The reaction yielded a $192 \mathrm{bp}$ amplicon. An aliquot $(5 \mu \mathrm{l})$ of PCR product was digested with $8 \mathrm{U}$ of FbaI (TaKaRa; Otsu, Shiga, Japan) and separated on a $3 \%$ agarose gel. The presence of the $1888 \mathrm{~T}$ allele creates an FbaI restriction site; digested amplicons from $1888 \mathrm{~T}$ homozygotes appear as a $170 \mathrm{bp}$ and a $22 \mathrm{bp}$ band, homozygotes for the $1888 \mathrm{C}$ allele appear as a $192 \mathrm{bp}$ band, and heterozygotes have all three of these bands.

For the C-2128T polymorphism, an amplification of a $164 \mathrm{bp}$ fragment using forward primer $5^{\prime}$-AGCTTGGAGCA TTGAAAGGA- $3^{\prime}$ and reverse primer $5^{\prime}$-ACGCACCCCAGAT GTAGGL-3' was performed. A Pst I recognition site was introduced by a one base mismatch (underlined) in the reverse primer. PCR conditions were identical to those for $\mathrm{C}-1888 \mathrm{~T}$, except for an annealing temperature of $55^{\circ} \mathrm{C}$. The 164 bp amplicon was digested with 8 U of PstI (TaKaRa) and separated on a $3 \%$ agarose gel. Homozygotes for the $2128 \mathrm{~T}$ allele yielded two restriction fragments of $145 \mathrm{bp}$ and $19 \mathrm{bp}$ after Pst I digestion, homozygotes for 2128C remained uncut ( $164 \mathrm{bp}$ band), and heterozygotes yielded all three of these bands.

Genotyping was performed by staff blinded to the subjects' case/control status. The accuracy of genotyping data for each SNP obtained from PCR-RFLP analyses was validated by direct sequencing of a $15 \%$ masked, random sample of cases and controls.

\section{Statistical analysis}

Genotype and allele frequencies for each SNP were determined by gene counting, and the significance of deviations from Hardy-Weinberg equilibrium was tested using the random permutation procedure implemented in the Arlequin package (http://gb.unige.ch/arlequin/). Logistic regression analysis was performed to evaluate whether there was association with susceptibility to NPC for each SNP after adjustment for age and gender, and $p$ value, odds ratios (OR), and $95 \%$ confidence intervals (CI) were calculated. Haplotype 


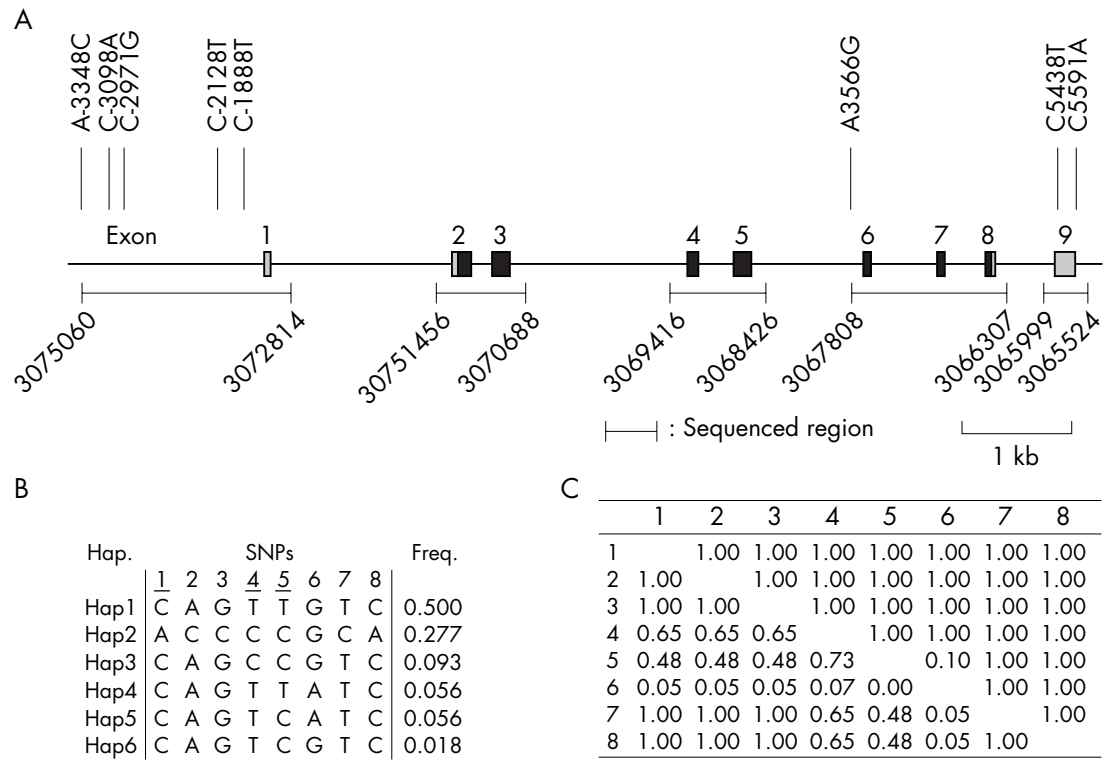

Figure 1 SNPs distribution haplotypes, and LD pattern of PLUNC. (A) Gene structure and location of SNPs of PLUNC. The positions of the eight SNPs are shown above the intron-exon structure of PLUNC. Coding exons are marked by black boxes, and 5' and 3' UTRs by grey boxes. The exact sequence regions investigated are indicated by first and last nucleotide position (GenBank accession no. GI:17458490). (B) PLUNC haplotypes: all eight SNPs were used to construct haplotypes (SNPs are numbered as in table 2). Three htSNPs (underlined) describe $95 \%$ of the haplotype diversity observed within the PLUNC region. (C) The pairwise LD measurement at PLUNC (SNPs are numbered as in table 2). The bottom left of the table indicates the values of $r^{2}$, and the top right absolute values of $D^{\prime}$. frequencies between NPC patients and controls were compared using the $\chi^{2}$ test. In view of the multiple comparisons in the case-control study, the correction factor $\mathrm{n}(\mathrm{m}-\mathrm{l})$ ( $\mathrm{n}$ loci with $\mathrm{m}$ alleles each) was applied to correct the significance level. These analyses were performed using SPSS software (version 9.0; SPSS Inc, Chicago, IL, USA).

The pairwise linkage disequilibrium (LD) measurement (Lewontin's $D^{\prime}$ and $\mathrm{r}^{2}$ ) calculation was performed using the Arlequin package. MatInspector (http://www.gsf.de/biodv/ matinspector.html) was used to search for candidate transcription factors that might bind to regions surrounding the SNPs we observed.

\section{RESULTS}

Resequencing of $5743 \mathrm{bp}$ of PLUNC genomic regions in the 27 samples revealed eight SNPs (table 2, fig 1A). Haplotypes were constructed on the basis of the genotype data from these eight SNPs using PHASE software. ${ }^{33}$ A 98\% PHASE assignment was made with more than $96 \%$ certainty. Six haplotypes were identified (fig 1B). Three common SNPs ( 1 , 4 , and 5, table 2), which captured more than $95 \%$ of the haplotype diversity observed within gene regions, were determined as htSNPs. In addition, the SNPs A-3348C, C-3098A, C-2971G, C5438T, and C5591A were in absolute LD in the Chinese sample $\left(\left|D^{\prime}\right|=1\right.$ and $r^{2}=1$, fig $\left.1 C\right)$, suggesting the polymorphism A-3348C can represent the other four SNPs as marker. We therefore selected polymorphisms A-3348C, C-2128T, and C-1888T as markers for subsequent genotyping analysis.

On the basis of logistic regression analysis with adjustment for age and gender, significant associations with the susceptibility to NPC were observed with the polymorphisms C-2128T and C-1888T (table 3). Subjects carrying the 2128C/ C genotype had an increased susceptibility to NPC compared with those carrying the $2128 \mathrm{~T} / \mathrm{T}$ genotype (OR 2.8; $95 \% \mathrm{CI}$ 1.7 to $4.9 ; \mathrm{p}=0.0006)$. Similarly, the $1888 \mathrm{C} / \mathrm{C}$ genotype was associated with an increased susceptibility to NPC compared with the $1888 \mathrm{~T} / \mathrm{T}$ genotype $(3.3 ; 1.8$ to 6.1 ; $\mathrm{p}<0.0001)$. The associations remained significant even after correction for multiple comparisons. No significant association was found between A-3348C and susceptibility to NPC. The genotype distributions for the three SNPs were in Hardy-Weinberg equilibrium (table 3 ).

\begin{tabular}{|c|c|c|c|c|c|}
\hline No. & SNP* & Frequencyt & Heterozygosity & Region & $\begin{array}{l}\text { dbSNP ID } \\
\text { number }\end{array}$ \\
\hline 1 & $A-3348 C$ & 0.278 & 0.401 & Promoter & rs1998149 \\
\hline 2 & C-3098A & 0.278 & 0.401 & Promoter & rs6059177 \\
\hline 3 & C-2971G & 0.278 & 0.401 & Promoter & rs6059178 \\
\hline 4 & $C-2128 \mathrm{~T}$ & 0.370 & 0.466 & Promoter & rs2752903 \\
\hline 5 & C-1888T & 0.444 & 0.494 & Promoter & rs750064 \\
\hline 6 & A3566G & 0.111 & 0.197 & Intron6 & rs2273529 \\
\hline 7 & C5438T & 0.278 & 0.401 & 3'UTR & rs 1047595 \\
\hline 8 & C5591A & 0.278 & 0.401 & 3'UTR & rs2295575 \\
\hline
\end{tabular}

Furthermore, we performed the haplotype analysis for evaluating the haplotype frequencies of SNPs located nearby at the same chromosome regions, trying to derive haplotypes specifically correlated with NPC. Haplotypes based on the polymorphisms C-2128T and C-1888T were constructed. Four haplotypes, T-T, C-T, T-C and C-C, were observed. The estimated haplotype distribution was significantly different between the NPC patients and controls, indicating that individuals with haplotype C-C had significantly increased susceptibility to NPC (OR 1.86; 95\% CI 1.34 to 2.56; $\mathrm{p}=0.00016$ ), even after correction for multiple comparisons (table 4).

\section{DISCUSSION}

In this study, we systematically screened SNPs in all exons, relevant intron-exon boundaries, and the approximately $2 \mathrm{~kb}$ promoter region of PLUNC, and from this, we identified eight SNPs. Two promoter SNPs, C-2128T and C-1888T, showed significant association with susceptibility to NPC. When compared with the statistical significance level required after correction for multiple testing, the associations remained significant. To our knowledge, this is the first report of the genetic association between PLUNC and susceptibility to NPC, indicating that PLUNC may play a role in the pathogenesis of this disorder. 


\begin{tabular}{|c|c|c|c|c|}
\hline Polymorphism & $\begin{array}{l}\text { NPC patients } \\
(n=239)\end{array}$ & $\begin{array}{l}\text { Controls } \\
(n=286)\end{array}$ & OR $(95 \% \mathrm{Cl})$ & $\mathbf{p}$ \\
\hline \multicolumn{5}{|l|}{$A-3348 C$} \\
\hline \multicolumn{5}{|l|}{ Genotype } \\
\hline$A / A$ & $9(3.9 \%)$ & $15(5.4 \%)$ & 1.0 & - \\
\hline $\mathrm{A} / \mathrm{C}$ & 90 (38.6\%) & $116(41.6 \%)$ & $1.3(0.6-3.1)$ & 0.564 \\
\hline $\begin{array}{l}\mathrm{C} / \mathrm{C} \\
\text { Allele }\end{array}$ & $134(57.5 \%)$ & $148(53.0 \%)$ & $1.5(0.6-3.6)$ & 0.342 \\
\hline A & $108(23.2 \%)$ & $146(26.2 \%)$ & 1.0 & - \\
\hline C & 358 (76.8\%) & 412 (73.8\%) & $1.2(0.9-1.6)$ & 0.273 \\
\hline \multicolumn{5}{|c|}{$\begin{array}{lll} & 0.28 \\
\end{array}$} \\
\hline \multicolumn{5}{|l|}{ Genotype } \\
\hline$T / T$ & $120(50.2 \%)$ & $160(56.9 \%)$ & 1.0 & - \\
\hline $\mathrm{T} / \mathrm{C}$ & $50(20.9 \%)$ & 81 (28.8\%) & $0.9(0.6-1.4)$ & 0.468 \\
\hline \multicolumn{5}{|l|}{ Allele } \\
\hline T & 290 (60.7\%) & 401 (71.4\%) & 1.0 & - \\
\hline C & 188 (39.3\%) & 161 (28.6\%) & $1.7(1.3-2.2)$ & 0.0009 \\
\hline \multicolumn{5}{|c|}{ 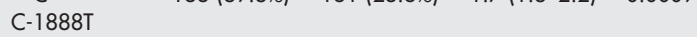 } \\
\hline \multicolumn{5}{|l|}{ Genotype } \\
\hline $\mathrm{T} / \mathrm{T}$ & 64 (27.6\%) & 99 (35.1\%) & 1.0 & - \\
\hline $\mathrm{T} / \mathrm{C}$ & $121(52.2 \%)$ & $163(57.8 \%)$ & $1.2(0.8-1.7)$ & 0.510 \\
\hline $\mathrm{C} / \mathrm{C}$ & $47(20.2 \%)$ & 20 (7.1\%) & $3.3(1.8-6.1)$ & \\
\hline \multicolumn{5}{|l|}{$\begin{array}{r}<0.0001 \\
\text { Allele }\end{array}$} \\
\hline T & $249(53.7 \%)$ & 361 (64.0\%) & 1.0 & - \\
\hline C & $215(46.3 \%)$ & 203 (36.0\%) & $1.6(1.2-2.0)$ & 0.001 \\
\hline
\end{tabular}

The frequencies of genotypes are indicated in absolute values and percentages in parentheses. The sums of genotypes in patients and controls do not add up to the total number of subjects, owing to failure of genotyping for some individuals. All ORs are adjusted for age and gender.

Although a number of SNPs within PLUNC have been identified, no study has so far addressed the functional consequences of these mutations. Computer analysis indicate that sequences surrounding the polymorphism C-2128T might bind transcription factor winged helix protein $(\mathrm{WHN})^{35}$ or Epstein-Barr virus transcription factor $\mathrm{R}$ (EBVR), ${ }^{36}$ and the sequences surrounding the C-1888T might bind transcription factor Xenopus forkhead domain factor 3 (XFD3), ${ }^{37}$ respectively. One mechanism by which this could occur is if the risky $2128 \mathrm{C} / 888 \mathrm{C}$ alleles and the $\mathrm{C}-\mathrm{C}$ haplotype are themselves functional variants that directly affect PLUNC production, for example, by influencing binding of transcription factors in the promoter region of this gene. We also cannot exclude the possibility of the presence of other candidate functional polymorphisms, because not all the introns of the PLUNC were investigated in the present study. Further studies are needed to identify all polymorphisms in this gene and clarify which polymorphism(s) or haplotype(s) may possess functional consequence(s) for PLUNC, and in turn to provide mechanistic plausibility for the observed association between polymorphisms/haplotypes and susceptibility to NPC.

The exact mechanism by which PLUNC may affect the susceptibility of NPC is not as yet clear. PLUNC is specifically expressed in the upper airways and nasopharyngeal regions. $^{21} 22{ }^{24}$ It has been suggested that the PLUNC may function in the innate immune response in areas of the mouth and nose $\mathrm{e}^{23}$ that are sites of significant bacterial or viral exposure. This role may be mediated by direct antibacterial action or by an indirect lipopolysaccharide sensing/neutralising activity. ${ }^{38}$ This is of particular relevance to NPC because the presence of Epstein-Barr virus is a well established risk factor for this disorder. ${ }^{267}$ Furthermore, PLUNC is found to be downregulated in NPC biopsies, ${ }^{24}$ indicating that it may be a candidate suppressor of NPC, and its abnormal expression may be an important molecular event in NPC. Thus, our current PLUNC genetic association data strongly suggest that
Table 4 Haplotype distribution in the patients with NPC and in controls

\begin{tabular}{|c|c|c|c|c|}
\hline Haplotype & $\begin{array}{l}\text { NPC patients } \\
(2 n=478)\end{array}$ & $\begin{array}{l}\text { Controls } \\
(2 n=572)\end{array}$ & OR $(95 \% \mathrm{Cl})$ & $\mathbf{p}^{*}$ \\
\hline T-T & 187 (41.2\%) & $292(53.7 \%)$ & 1 & - \\
\hline C-T & 57 (12.6\%) & $56(10.3 \%)$ & $1.59(1.05-2.40)$ & 0.027 \\
\hline $\mathrm{T}-\mathrm{C}$ & 90 (19.8\%) & 95 (17.5\%) & $1.48(1.05-2.08)$ & 0.024 \\
\hline $\mathrm{C}-\mathrm{C}$ & $120(26.4 \%)$ & 101 (18.5\%) & $1.86(1.34-2.56)$ & 0.00016 \\
\hline Total (3 df) & & & & 0.001 \\
\hline \multicolumn{5}{|c|}{$\begin{array}{l}\text { The frequencies of haplotypes are indicated in absolute values and } \\
\text { percentages in parentheses. Haplotype is constructed based on C-2128T } \\
\text { and C-1888T. The sums of genotypes in patients and controls do not add up } \\
\text { to the total number of subjects, owing to failure of genotyping for some } \\
\text { individuals. *No correction was made for testing multiple alleles. }\end{array}$} \\
\hline
\end{tabular}

PLUNC may directly affect the susceptibility of NPC. This study, however, does not exclude the possibility that the effect observed here could be attributable to linkage disequilibrium with functional polymorphisms in nearby genes. Indeed, the $\operatorname{loss}^{27} 28$ or gain ${ }^{29}$ of chromosome arm $20 \mathrm{q}$ has been previously described in NPC. Additional analyses of the nearby genes may help to verify the possibility.

In reviewing the results of this study, one potential limitation must be kept in mind. A number of association studies have addressed identification of the genes that may relate to the susceptibility to NPC. ${ }^{4-19}$ Most of the results, however, could not be replicated in subsequent studies in other populations. Although the highly significant association between PLUNC and susceptibility of NPC derived from a biologically based a priori hypothesis, our initial findings should be independently verified in other populations with high incidence rates of NPC, such as other southern Chinese, Singaporeans, and Taiwanese.

In conclusion, we have shown that PLUNC may be a genetic risk factor for NPC in Cantonese speaking Chinese patients. Knowledge of genetic factor contributing to the pathogenesis of the NPC as presented here could lead to improved treatment and prevention of this disorder.

\section{ACKNOWLEDGEMENTS}

This study was supported by grants from the Chinese High-tech Program, the Medicine and Health Research Program, the Science Fund for Creative Research Groups, and the Major Program of Guangdong Province.

\section{Authors' affiliations}

K Yao, Cancer Research Institute of Central South University, Changsha, China

K Yao, Y He, L Lv, Institute of Cancer Research, The First Military Medical University, Guangzhou, China

F He, G Zhou, Y Zhai, Department of Genomics \& Proteomics, Beijing Institute of Radiation Medicine, Beiijing, China

F He, G Zhou, X Dong, Chinese National Human Genome Center at Beijing, Beijing, China

$\mathrm{F} \mathrm{He}$, School of Life Science \& Technology, Tsinghua University, Beijing, China

Competing interests: none declared

The first two authors contributed equally to this work.

Correspondence to: Dr F He, Department of Genomics \& Proteomics, Beijing Institute of Radiation Medicine, 27 Taiping Road, Beijing 100850, China; hefc@nic.bmi.ac.cn; and Dr K Yao, Institute of Cancer Research, The First Military Medical University, Guangzhou, 510515, China; ktyao@fimmu.com

Received 10 May 2004

Revised 26 June 2004

Accepted 28 June 2004 


\section{REFERENCES}

1 Parkin DM, Laara E, Muir CS. Estimates of the worldwide frequency of sixteen major cancers in 1980. Int J Cancer 1988;41:184-97.

2 Hildesheim A, Levine PH. Etiology of nasopharyngeal carcinoma: a review. Epidemiol Rev 1993;15:466-85.

3 Simons MJ, Wee GB, Goh EH, Chan SH, Shanmugaratnam K, Day NE, deThe GB. Immunogenetics aspects of nasopharyngeal carcinoma (NPC). IV. Increased risk in Chinese for NPC associated with a Chinese-related HLA profile (A2, Singapore2). J Nat Cancer Inst 1976;57:977-80.

4 Hildesheim A, Chen CJ, Caporaso NE, Cheng YJ, Hoover RN, Hsu MM, Levine PH, Chen IH, Chen JY, Yang CS. Cytochrome P4502El genetic polymorphisms and risk of nasopharyngeal carcinoma: results from a casecontrol study conducted in Taiwan. Cancer Epidemiol Biomarkers Prev 1995:4:607-10

5 Simons MJ, Wee GB, Day NE, Morris PJ, Shanmugaratnam K, de-The GB. Immunogenetic aspects of nasopharyngeal carcinoma: I. Differences in HLA antigen profiles between patients and control groups. Int J Cancer $1974 ; 13: 122-34$

6 Klein G, Giovanella BC, Lindahl T, Fialkow PJ, Singh S, Stehlin JS. Direct evidence for the presence of Epstein-Barr virus DNA and nuclear antigen in malignant epithelial cells from patients with poorly differentiated carcinoma of the nasopharynx. Proc Natl Acad Sci USA 1974;71:4737-41

7 Tsai ST, Jin YT, Su IJ. Expression of EBERI in primary and metastatic nasopharyngeal carcinoma tissues using in situ hybridization. A correlation with WHO histologic subtypes. Cancer 1996;77:231-6.

8 Yu MC, Ho JH, Lai SH, Henderson BE. Cantonese-style salted fish as a cause of nasopharyngeal carcinoma: report of a case-control study in Hong Kong. Cancer Res 1986;46:956-61.

9 Chen CJ, Liang KY, Chang YS, Wang YF, Hsieh T, Hsu MM, Chen JY, Liu MY. Multiple risk factors of nasopharyngeal carcinoma: Epstein-Barr virus, malarial infection, cigarette smoking and familial tendency. Anticancer Res 1990:10:547-53

10 Ward MH, Pan WH, Cheng YJ, Li FH, Brinton LA, Chen CJ, Hsu MM, Chen IH, Levine PH, Yang CS, Hildesheim A. Dietary exposure to nitrite and nitrosamines and risk of nasopharyngeal carcinoma in Taiwan. Int J Cancer 2000;86:603-9.

11 Lu SJ, Day NE, Degos L, Lepage V, Wang PC, Chan SH, Simons M, McKnight B, Easton D, Zeng Y, de-The G. Linkage of a nasopharyngeal carcinoma susceptibility locus to the HLA region. Nature 1990;346:470-1.

12 Feng BJ, Huang W, Shugart YY, Lee MK, Zhang F, Xia JC, Wang HY, Huang TB, Jian SW, Huang $P$, Feng QS, Huang LX, Yu XJ, Li D, Chen LZ, Jia $W H$, Fang $Y$, Huang $H M$, Zhu JL, Liu $X M$, Zhao $Y$, Liu WQ, Deng $M Q$, Hu WH, Wu SX, Mo HY, Hong MF, King MC, Chen Z, Zeng YX. Genomewide scan for familial nasopharyngeal carcinoma reveals evidence of linkage to chromosome 4. Nat Genet, 2002 31, 395-9.

13 Xiong W, Zeng ZY, Xia JH, Xia K, Shen SR, Li XL, Hu DX, Tan C, Xiang JJ Zhou J, Deng H, Fan SQ, Li WF, Wang R, Zhou M, Zhu SG, Lu HB, Qian J, Zhang BC, Wang JR, Ma J, Xiao BY, Huang $H$, Zhang QH, Zhou YH, Luo XM, Zhou HD, Yang YX, Dai HP, Feng GY, Pan Q, Wu LQ, He L, Li GY. A susceptibility locus at chromosome $3 p 21$ linked to familial nasopharyngeal carcinoma. Cancer Res 2004:64:1972-4.

14 Dardari R, Khyatti $M$, Jouhadi $H$, Benider A, Ettayebi $H$, Kahlain $H$, Mansouri A, El Gueddari B, Benslimane A. Study of human leukocyte antigen class I phenotypes in Moroccan patients with nasopharyngeal carcinoma. Int J Cancer $2001 ; 92: 294-7$.

15 Mokni-Baizig N, Ayed K, Ayed FB, Ayed S, Sassi F, Ladgham A, Bel Hadi O, El May A. Association between HLA-A/-B antigens and-DRB1 alleles and nasopharyngeal carcinoma in Tunisia. Oncology 2001;61:55-8.

16 Goldsmith DB, Morton TM, West R. HLA associations with nasopharyngeal carcinoma in Southern Chinese: a Meta analysis. Clin Otolaryngol 2002;27:61-7.

17 Jalbout M, Bouaouina N, Gargouri J, Corbex M, Ben Ahmed S, Chouchane L. Polymorphism of the stress protein HSP7O-2 gene is associated with the susceptibility to the nasopharyngeal carcinoma. Cancer Lett 2003;193:75-81

18 Deng L, Zhao XR, Pan KF, Wang Y, Deng XY, Lu YY, Cao Y. Cyclin D1 polymorphism and the susceptibility to NPC using DHPLC. Sheng Wu Hua Xue Yu Sheng Wu Wu Li Xue Bao (Shanghai) 2002;34:16-20.
19 Nazar-Stewart V, Vaughan TL, Burt RD, Chen C, Berwick M, Swanson GM. Glutathione S-transferase $M 1$ and susceptibility to nasopharyngeal carcinoma. Cancer Epidemiol Biomarkers Prev 1999;8:547-51.

20 Weston WM, LeClair EE, Trzyna W, McHugh KM, Nugent P, Lafferty CM, Ma L, Tuan RS, Greene RM. Differential display identification of plunc, a novel gene expressed in embryonic palate, nasal epithelium, and adult lung. J Biol Chem 1999;274:13698-703.

21 He ZW, Xie L, Xu LG, Lan K, Liu W, Zhang L, Ren C, Shi J, Zhou W, Yao K. Cloning of a novel gene associated with human nasopharyngeal carcinoma. Chin Sci Bull 2000:45:2267-72.

22 Bingle CD, Bingle L. Characterisation of the human plunc gene, a gene product with an upper airways and nasopharyngeal restricted expression pattern. Biochim Biophys Acta 2000;1493:363-7.

23 Sung YK, Moon C, Yoo JY, Moon C, Pearse D, Pevsner J, Ronnett GV. Plunc, a member of the secretory gland protein family, is up-regulated in nasal respiratory epithelium after olfactory bulbectomy. J Biol Chem 2002;277:12762-9.

24 Zhang B, Nie X, Xiao B, Xiang J, Shen S, Gong J, Zhou M, Zhu S, Zhou J, Qian J, Lu H, He X, Li X, Hu G, Li G. Identification of tissue-specific genes in nasopharyngeal epithelial tissue and differentially expressed genes in nasopharyngeal carcinoma by suppression subtractive hybridization and cDNA microarray. Genes Chromosomes Cance 2003;38:80-90.

25 Di YP, Harper R, Zhao Y, Pahlavan N, Finkbeiner W, Wu R. Molecular cloning and characterization of spurt, a human novel gene that is retinoic acid-inducible and encodes a secretory protein specific in upper respiratory tracts. J Biol Chem 2003;278:1 165-73.

26 Tomer Y, Barbesino G, Greenberg DA, Concepcion E, Davies TF. A new Graves disease-susceptibility locus maps to chromosome $20 q 11.2$. International Consortium for the Genetics of Autoimmune Thyroid Disease. Am J Hum Genet 1998;63:1749-56.

27 Mutirangura A, Tanunyutthawongese C, Pornthanakasem W, Kerekhanjanarong V, Sriuranpong V, Yenrudi S, Supiyaphun P, Voravud N. Genomic alterations in nasopharyngeal carcinoma: loss of heterozygosity and Epstein-Barr virus infection. Br J Cancer 1997;76:770-6.

28 Lo KW, Teo PM, Hui AB, To KF, Tsang YS, Chan SY, Mak KF, Lee JC, Huang DP. High resolution allelotype of microdissected primary nasopharyngeal carcinoma. Cancer Res 2000;60:3348-53.

29 Fan CS, Wong N, Leung SF, To KF, Lo KW, Lee SW, Mok TS, Johnson PJ, Huang DP. Frequent c-myc and Int-2 overrepresentations in nasopharyngeal carcinoma. Hum Pathol 2000;31:169-78.

30 Zhou GQ, Zhai Y, Dong XJ, Li Y, Zhang XM, Zhang RF, Li SQ, Li XH, He FY, Wei HD, Chen XP, Yao ZJ, Shen Y, Qiang BQ, He FC. Variants in TNFRSF5 locus and association analysis with hepatitis $B$ virus (HBV) infection. Hum Mutat 2004;23:99-100.

31 Zhou GQ, Zhai Y, Dong XJ, Zhang XM, He FY, Zhou KX, Zhu YP, Wei HD Yao ZJ, Zhong SF, Shen Y, Qiang BQ, He FC. Haplotype structure and evidence for positive selection at the human IL13 locus. Mol Biol Evol 2004;21:29-35.

32 Kruglyak L, Nickerson DA. Variation is the spice of life. Nat Genet 2001;27:234-6.

33 Stephens $M$, Smith NJ, Donnelly P. A new statistical method for haplotype reconstruction from population data. Am J Hum Genet 2001;68:978-89.

34 Johnson GC, Esposito L, Barratt BJ, Smith AN, Heward J, Di Genova G, Ueda H, Cordell HJ, Eaves IA, Dudbridge F, Twells RC, Payne F, Hughes W, Nutland S, Stevens H, Carr P, Tuomilehto-Wolf E, Tuomilehto J, Gough SC, Clayton DG, Todd JA. Haplotype tagging for the identification of common disease genes. Nat Genet 2001;29:233-7.

35 Schlake T, Schorpp M, Nehls M, Boehm T. The nude gene encodes organisms that lack an anticipatory immune system. Proc Natl Acad Sci USA 1997;94:3842-7.

36 Gruffat $H$, Sergeant A. Characterization of the DNA-binding site repertoire for the Epstein-Barr virus transcription factor R. Nucleic Acids Res 1994;22:1172-8

37 Kaufmann E, Mueller D, Knoechel W. DNA recognition site analysis of Xenopus winged helix proteins. J Mol Biol 1995:248:239-54.

38 Bingle CD, Craven CJ. PLUNC: a novel family of candidate host defence proteins expressed in the upper airways and nasopharynx. Hum Mol Genet 2002; 11:937-43 